\title{
Cultivar Decline in Sweetpotato: I. Impact of Micropropagation on Yield, Storage Root Quality, and Virus Incidence in 'Beauregard'
}

\author{
A.D. Bryan \\ Department of Horticultural Science, North Carolina State University, Raleigh, NC 27695 \\ Z. Pesic-VanEsbroeck \\ Department of Plant Pathology, North Carolina State University, Raleigh, NC 27695 \\ J.R. Schultheis and K.V. Pecota \\ Department of Horticultural Science, North Carolina State University, Raleigh, NC 27695 \\ W.H. Swallow \\ Department of Statistics, North Carolina State University, Raleigh, NC 27695 \\ G.C.Yencho ${ }^{1}$ \\ Department of Horticultural Science, North Carolina State University, Raleigh, NC 27695
}

Additional InDex words. Ipomoea batatas, meristem-tip culture, clonal degradation, genetic drift, Sweet potato feathery mottle virus

\begin{abstract}
Decline in sweetpotato yield and storage root quality has been attributed to the accumulation of viruses, pathogens and mutations. To document the effects of decline on yield and storage root quality, two micropropagated, virus-indexed, greenhouse produced G1 'Beauregard' meristem-tip cultured clones, B94-14 and B94-34, were compared with 1) micropropagated B94-14 and B94-34 clones propagated adventitiously up to five years in the field (G2, G3, G4, G5); and 2) nonmicropropagated, unimproved stock of 'Beauregard' seed in field trials during 1997 to 2001 . At least three trials were located each year in sweetpotato producing regions in North Carolina. In 2000 and 2001, two trials were monitored weekly for foliar symptoms of Sweet potato feathery mottle virus (SPFMV) and other potyviruses, and virus-indexed for selected viruses using Ipomoea setosa and nitrocellulose enzyme linked immunosorbant assays (NCMELISA). Only SPFMV was detected in field samples using NCM-ELISA, but this does not rule out the presence of newly described viruses infecting sweetpotato for which tests were unavailable. Monitoring indicated that all G1 plants became infected with SPFMV by the end of the growing season, and that G2 to G5 plants were probably infected in their initial growing season. G1 plants consistently produced higher total yield, total marketable yield (TMY), U.S. No. 1 root yield and percent No. 1 yield than G2 to G5 plants. G1 plants also produced storage roots with more uniform shapes and better overall appearance than storage roots produced from G2 to G5 plants. Also, G2 to G5 storage roots tended to be longer than G1 storage roots. Rank mean yield and storage root quality measurements of each location were consistent with means averaged over locations per year and suggested a decrease in yield and storage root quality with successive seasons of adventitious propagation. Linear regression analysis used to model yield and storage root quality measurements of seed generations G1 to G5 indicated that total yield, TMY, No. 1 yield, percent No. 1 yield, shape uniformity, and overall appearance decreased gradually, and that length/diameter ratios increased gradually with generation. The rate of decline in No. 1 yield was greater for B94-34 compared to B94-14. Both viruses and mutations of adventitious sprouts arising from storage roots probably contribute to cultivar decline in sweetpotato, but further studies are needed to determine their relative importance. A simple profitability analysis for G1 vs. G2-G4 planting material conducted to facilitate better understanding of the economics of using micropropagated planting material to produce a crop in North Carolina revealed that growers have a potential net return of \$2203/ha for G1 plants, $\$ 5030 /$ ha for G2 plants, and \$4394/ha for G5 plants. Thus, while G1 plants generally produce higher No. 1 yields, a greater monetary return can be achieved using G2 planting materials because of the high costs associated with producing G1 plants. Based on this analysis, the best returns are accrued when growers plant their crop using G2 and/or G3 seed.
\end{abstract}

Received for publication 8 Jan. 2003. Accepted for Publication 2 June 2003. This paper is a portion of a thesis submitted by Adrienne D. Bryan. The research was supported by the N.C. Agricultural Foundation, the N.C. Crop Improvement Association, the N.C. Sweetpotato Commission, and the N.C. Sweetpotato Certified Seed Growers Association. We thank Marilyn Daykin for meristem-tip culture procedures, Lauren Upton and Jennifer Smith for assistance with greenhouse and field work, Charles W. Averre and Dennis Adams for assistance in harvest and evaluations, and Sandy Barnes, Randy Herring and the staff at the Cunningham Research Station, Kinston, NC and the staff at the Horticultural Crops Research Station, Clinton, NC who managed the field tests and assisted with harvest. We also greatly appreciate the cooperation of Extension Associate, Bill Jester, County Agents Billy Little and Milton Parker, and sweetpotato growers George Wooten, Dale Bone, Jerome Vick, Ralph and Sylvia Batchelor, and Sonny Scott. ${ }^{1}$ Corresponding author; e-mail Craig_Yencho@ncsu.edu.
Sweetpotato can be propagated asexually via roots or stems. In the United States, growers multiply sweetpotatoes asexually by saving a portion of the year's crop as seed roots. In early spring, the seed storage roots are planted in beds, and adventitious sprouts arising from these roots are cut and transplanted to the field to produce the next crop. After several years of adventitious propagation via storage roots, yield and root quality are often reduced. The reduction of storage root quality and yield in sweetpotato, referred to as cultivar running-out (Miller et al., 1959) or decline has been attributed to the accumulation of viruses, pathogens and mutations (Clark et al., 2002; Villordon and La Bonte, 1995).

Mutations in sweetpotato induce color changes in the root epi- 
dermis and flesh (Groth, 1911; Harter, 1926; Miller, 1930, 1935; Rosa, 1926; Thompson, 1929). Mutations are also responsible for genetic variability resulting in a range of shapes and yields among clones of a given cultivar (Edmond and Ammerman, 1971; Villordon and La Bonte, 1995). If deleterious mutations are not detected by visual selection, a widely used method of preserving the genetic integrity of cultivars in U.S. sweetpotato seed certification programs (Dangler, 1994), they may accumulate and alter favorable genetic components for yield and storage root quality. Nodal cuttings of sweetpotato have lower mutation rates than adventitious sprouts derived from saved storage roots (Templeton-Somers and Collins, 1986; Villordon and La Bonte, 1995, 1996). Thus, the use of planting material derived from preexisting meristematic tissue, i.e., nodal cuttings, has been proposed to reduce clonal variability in sweetpotato seed certification programs (Villordon and La Bonte, 1995, 1996).

In addition to mutations, viral infections contribute to sweetpotato cultivar decline (Clark et al., 2002; Gooding, 1964; Huett, 1981). Accumulation of viruses and diseases occurs through the adventitious, root-to-sprout propagation method used in commercial production. Saved seed roots of sweetpotato plants that become infected with viruses during the growing season will produce virus-infected adventitious sprouts (Clark and Moyer, 1988). If virus infection decreases yield and storage root quality in sweetpotato, then the continuous use of virus-infected adventitious sprouts will also lead to cultivar decline. Consequently, the use of sweetpotato planting material that is free of known viruses is recommended as a method of controlling, preventing, or slowing virus accumulation in subsequent plantings (Clark and Moyer, 1988).

In North Carolina, several studies have been conducted to compare the effects of yield and storage root quality of nodal cuttings from micropropagated plants with nonmicropropagated, virus infected plants from various sources. Sweet potato feathery mottle virus (SPFMV) occurs worldwide, and it is the most common virus of sweetpotato in the United States (Clark and Moyer, 1988). Depending on the SPFMV strain and sweetpotato cultivar, symptoms of infection include various foliar discolorations and storage root abnormalities such as russet crack and internal cork

Table 1. Location, planting and harvest date, and the number of days in the growing season for sweetpotato field trials conducted in each year.

\begin{tabular}{llccc}
\hline Year & Site $^{z}$ & $\begin{array}{c}\text { Planting } \\
\text { date }\end{array}$ & $\begin{array}{c}\text { Harvest } \\
\text { date }\end{array}$ & $\begin{array}{c}\text { No. of } \\
\text { days }\end{array}$ \\
\hline 1999 & Clinton & 23 June & 29 Sept. & 98 \\
& Columbus County & 15 June & 6 Oct. & 113 \\
& Kinston (early) & 20 May & 24 Aug. & 96 \\
& Kinston (late) & 9 June & 7 Oct. & 120 \\
& Wilson County & 22 June & 14 Oct. & 114 \\
2000 & Columbus County & 23 May & 14 Sept. & 112 \\
& Kinston & 15 June & 28 Sept. & 105 \\
& Nash County & 8 June & 21 Sept. & 105 \\
\multirow{2}{*}{2001} & Clinton & 23 May & 4 Sept. & 114 \\
& Columbus County & 12 June & 4 Oct. & 114 \\
& Kinston & 6 June & 20 Sept. & 106 \\
& Wilson County & 8 June & 25 Sept. & 109 \\
\hline
\end{tabular}

zTrials were conducted at the following sites: Cunningham Research Station, Kinston, N.C.; Horticultural Crops Research Station, Clinton, N.C.; and sweetpotato farms in Wilson County, Nash County, and Columbus County.

y Number of days indicates the length of the growing season for each trial.
(Clark and Moyer, 1988). The studies conducted in North Carolina with 'Beauregard' suggested that the use of micropropagated plants, in addition to reducing incidence of SPFMV and possibly other newly described potyviruses (Moyer et al., 2002; Souto et al., 2003), provided planting material that yielded as good as or better than nonmicropropagated, SPFMV-infected plants that had been in field production for several years (Averre et al., 1993; Jester et al., 1994; Schultheis, 1994; Schultheis et al., 1994). However, the effects of viruses on yield and quality over several generations of propagation were not studied.

The primary objectives of this study were to document the changes observed in sweetpotato yield and quality over successive generations of adventitious propagation, determine the rate at which micropropagated plants are infected with viruses during the growing season, and construct predictive models with respect to yield and various storage root quality attributes over seed generations to determine how quickly sweetpotato cultivar decline becomes economically significant to sweetpotato growers.

\section{Materials and Methods}

STUDY DESIGN. Micropropagated, virus-indexed, greenhouseproduced $\mathrm{G} 1(\mathrm{G}=$ generation and $1=$ number of seasons present in the field) B94-14 and B94-34 'Beauregard' mericlones were compared to 1) B94-14 and B94-34 clones propagated over successive years (G2 to G5) in the field and 2) nonmicropropagated 'Beauregard' stock, in a 5-year study. The experiments were initiated in 1997 when adventitious propagules derived from B94-14 G1 and B94-34 G1 storage roots produced by the 1996 crop were compared to G1 nodal cuttings of B94-14 and B94-34. Each subsequent year, successive and cumulative seed generations of B94-14 and B94-34 were included with the following comparisons being made: $\mathrm{G} 1$ and $\mathrm{G} 2$ in $1998 ; \mathrm{G} 1, \mathrm{G} 2$, and $\mathrm{G} 3$ in 1999; G1, G2, G3, and G4 in 2000; and G1, G2, G3, G4, and G5 in 2001. All the field trials included nonmicropropagated stock of 'Beauregard' for comparison. Trials conducted in 1999, 2000, and 2001 are reported herein.

Plant material. The micropropagated B94-14 and B94-34 were selected as improved 'Beauregard' clones after extensive testing in North Carolina (unpublished data). They were selected in 1994 from a planting of 'Beauregard' (Rolston et al., 1987) clone B73, which was obtained from Harold Edelman, Indiana Bio-Labs, who received B73 as virus-indexed, in-vitro plants from Christopher Clark, Plant Pathology Department, Louisiana State University in 1993. The B73 materials were increased to $\approx 7000$ plants in 1993 via vegetative propagation during the spring in greenhouses at the Lenoir County Extension Office, Kinston, N.C., and planted in an isolated sweetpotato field in Greene County, N.C., to minimize SPFMV infection. Storage roots were harvested, stored and bedded in Spring 1994, and plants obtained from these beds were planted at the Upper Coastal Plains Research Station, Rocky Mount, N.C., during the summer and superior hills selected at harvest. All the initial selections ( $>25$ ) were subjected to meristem-tip culture, virus-indexing, and extensive field evaluation by the Micropropagation Program at the North Carolina State University (NCSU) Micropropagation Unit (MPU), and B94-14 and B94-34 were judged to be the best. All procedures followed guidelines of the Food and Agriculture Organization of the United Nations and the International Board for Plant Genetic Resources (Moyer et al., 1989). Virus-indexed, true-to-type, vegetative planting-stock of each mericlone was maintained in insect-proof cages to avoid virus reinfection. A 
nonmicropropagated, virus-infected, 'Beauregard' clone maintained by the NCSU Sweetpotato Breeding and Genetics Program was included in the study for comparison.

G1 PLANTS. G1 transplants of both mericlones were obtained from nodal cuttings of micropropagated mother plants (i.e., G0 stock grown directly from tissue culture, virus-indexed, and maintained in insect-free greenhouses). Mother plants of each mericlone were established in $15-\mathrm{cm}$ pots filled with sand and kept in screen cages (52 mesh, $\left.460 \mu \mathrm{m}^{2}\right)$ in greenhouses with a 16-h photoperiod and a temperature range of 25 to $28^{\circ} \mathrm{C}$ at the MPU. Each mother plant was treated with $1 \mathrm{~g} /$ pot of Marathon $1 \%$ Granular Greenhouse and Nursery Insecticide (imidacloprid, Olympic Horticultural Products, Mainland, Pa.) every 6 to 8 weeks, $1 \mathrm{~g} /$ pot Miracle GroAll Purpose (15-30-15) water soluble fertilizer (The Scotts Co., Marysville, Ohio) once weekly, and $1 \mathrm{~g} /$ pot of $14 \mathrm{~N}-4.2 \mathrm{P}-11.6 \mathrm{~K}$ slow release fertilizer every two to three months as needed. Plants were watered daily. The same mother plants for each mericlone were used in all years. To increase the number of plants, two-node cuttings were taken from micropropagated mother plants and established in $200 \mathrm{~cm}^{3}$ cells of a 25-cell tray IPLRigi-Pots (model IP200; Stuewe \& Sons, Inc., Corvallis, Ore.) containing moist Metro-Mix (The Scotts Co., Marysville, Ohio). Each cutting was made with a sterile single-edge razor blade. Plant multiplication was continued through repeated two-node cuttings and increase plantings in 25-cell trays. Plants of each mericlone were placed in screen cages $\left(52\right.$ mesh, $\left.460 \mu \mathrm{m}^{2}\right)$ to prevent the introduction of aphids and potential virus infection.

G2, G3, G4, AND G5 PLANTS. Successive root to sprout propagules (G2, G3, G4, and G5) were obtained from cuttings of adventitious sprouts produced from bedded seed saved from the harvested roots used in tests from the previous year, as described earlier. Saved seed of each generation included a random selection of U.S. No. 1 and canner grade roots (diameter of 5 to $\leq 9 \mathrm{~cm}$ and length of 7.5 to $\leq 23 \mathrm{~cm}$ and diameter of 2.5 to $\leq 5 \mathrm{~cm}$, and length of 5 to $\leq 18 \mathrm{~cm}$, respectively) from each plot. Seed storage roots of non virus-tested, unimproved 'Beauregard' (hereafter referred to as 'Beauregard') were obtained from U.S. No. 1 and canner grade roots in field tests conducted by the NCSU Sweetpotato Breeding and Genetics Program at the NCSU Cunningham Research Station, Kinston, N.C. Seed storage roots of each generation $(\mathrm{G} 2$, G3, etc.) and 'Beauregard' were cured, stored, and bedded in the following spring after harvest to provide adventitious propagules to plant the trials conducted the following growing season. The process of curing, storing, and bedding was conducted following published recommendations (Sanders, 2001; Wilson and Averre, 1989). Stems of G1 plants and adventitious sprouts of G2 to G5 and 'Beauregard' stock of uniform length $(20 \mathrm{~cm})$ were cut one day before planting.

TRIAL DESIGN. The trials were located in the primary sweetpotato growing areas of North Carolina, and included 1) the Cunningham Research Station, Kinston; 2) the Horticultural Crops Research Station, Clinton; 3) on-farm, Columbus County; 4) on-farm, Nash County; and 5) on-farm, Wilson County. Each year, at least three locations including one research station and two on-farm locations were used for tests. Each test was arranged in a randomized complete block design with five replications. Plots were $6.1 \mathrm{~m}$ in length and rows were formed on 1.1-m centers. Each plot consisted of 25 plants spaced $23 \mathrm{~cm}$ apart. Border plants (G1) of the white-fleshed sweetpotato cultivar O'Henry were included at the end of each plot at the same spacing to minimize border effects and clearly separate plots at harvest.

Planting Procedures. Trials conducted in 1999, 2000, and
2001 and their corresponding location and planting and harvest dates are listed in Table 1. The soil series and texture for each location was a Norfolk loamy sand (fine-loamy, kaolinitic, thermic Typic Kandiudults). In 1999, B94-14 (G1, G2, and G3), B94-34 (G1, G2, and G3) and 'Beauregard' stock were tested in five field trials. Two separate trials, an early and a later planting were conducted at Kinston. In 2000, B94-14 (G1, G2, G3, and G4), B94-34 (G1, G2, G3, and G4) and 'Beauregard' stocks were tested in three field trials. In 2001, B94-14 (G1, G2, G3, G4, and G5), B94-34 (G1, G2, G3, G4, and G5), and 'Beauregard' stocks were compared in four field trials. On-farm trials were planted and grown using recommended cultural and pest management practices (Sanders, 2001; Wilson and Averre, 1989). Fertilization and cultivation practices varied due to grower preference and equipment with each on-farm trial. With on-farm trials, at least three cultivations with incorporation of fertilizer applications were conducted at $\approx 1,2$, and 4 weeks after planting (WAP). Generally, on-farm applications included $30 \mathrm{~kg} \cdot \mathrm{ha}^{-1}$ of $\mathrm{P}, 93 \mathrm{~kg} \cdot \mathrm{ha}^{-1}$ of $\mathrm{K}$, and $1.1 \mathrm{~kg} \cdot \mathrm{ha}^{-1}$ of $\mathrm{B}$ at the first cultivation, $112 \mathrm{~kg} \cdot \mathrm{ha}^{-1}$ of $\mathrm{K}$ at the second cultivation, and $57 \mathrm{~kg} \cdot \mathrm{ha}^{-1}$ of $\mathrm{N}$ at the third cultivation. The fertility regime for the Horticultural Crops Research Station trials in Clinton included three cultivations at $\approx 1,2$, and 4 WAP. Fertilizer application of $18 \mathrm{~kg} \cdot \mathrm{ha}^{-1}$ of $\mathrm{N}$ and $45 \mathrm{~kg} \cdot \mathrm{ha} \mathrm{a}^{-1}$ of $\mathrm{K}$ was incorporated into the first cultivation, $25 \mathrm{~kg} \cdot \mathrm{ha}^{-1}$ of $\mathrm{P}$ and 116 $\mathrm{kg} \cdot \mathrm{ha}^{-1}$ of $\mathrm{K}$ into the second, and $57 \mathrm{~kg} \cdot \mathrm{ha}^{-1}$ of $\mathrm{N}$ into the third cultivation. The fertility regime for the Cunningham Research Station trials in Kinston included two cultivations at $\approx 1$ and 4 WAP. Fertilizer application of $30 \mathrm{~kg} \cdot \mathrm{ha}^{-1}$ of P, $140 \mathrm{~kg} \cdot \mathrm{ha}^{-1}$ of $\mathrm{K}$, and $1.1 \mathrm{~kg} \cdot \mathrm{ha}^{-1}$ of $\mathrm{B}$ was incorporated into the first cultivation and $52 \mathrm{~kg} \cdot \mathrm{ha}^{-1}$ of $\mathrm{N}$ into the second cultivation.

At harvest, sweetpotatoes were graded according to U.S. Ntional Sweetpotato Collaborator standards, which classify harvested storage roots into U.S. No. 1 roots (diameter of 5 to $\leq 9 \mathrm{~cm}$ and length of 7.5 to $\leq 23 \mathrm{~cm}$ ), canner roots (diameter of 2.5 to $\leq 5 \mathrm{~cm}$ and length of $\leq 18 \mathrm{~cm}$ ), jumbo roots (diameter $>9 \mathrm{~cm}$, or length $>23 \mathrm{~cm}$ ), and cull roots (malformed or distorted roots). Yield measurements including total marketable yield (TMY), which includes all grades except culls, were recorded for each grade. The percentage of No. 1 (percent No. 1) roots was calculated relative to the total yield for each plot. At least three researchers (the authors) evaluated the quality of the collective total No. 1 roots for each experimental plot, including overall appearance and shape uniformity. Root quality measurements were recorded on a 0 to 5 scale to the nearest half unit where 5 represented the overall appearance and attractiveness of the roots and overall uniformity of storage root shapes (i.e., what percentage of the roots were similarly shaped). In addition, the No. 1 roots were rated visually for length to diameter (L/D) ratios. Ratings were recorded on a 1 to 5 scale to the nearest half unit where a 1 indicated that most of the storage roots were completely round (i.e., length $=$ width), and a 5 indicated that most of the roots were at least five times longer than the root width at its maximum width (i.e., length $\geq 5 \times$ the maximum width).

Virus MONITORING. Tests in the 2000 Kinston and Nash County locations and 2001 Kinston and Wilson County locations were monitored for symptoms typical of SPFMV and other potyviruses. In 2000 , weekly observations began $\approx 4$ WAP. However, due to the large percentage of symptomatic plants recorded at 4 WAP in 2000 , monitoring was initiated 1 WAP in 2001 . Weekly observations of the number of virus symptomatic plants were recorded for each plot in each year. Before harvest, symptomatic vines $(\approx 0.3$ $\mathrm{m}$ in length) of three randomly selected plants were chosen per 
plot, cut, and grafted onto the indicator plant, Ipomoea setosa, to test for the presence of viruses. Indicator plants showing severe virus symptoms were tested for SPFMV, Sweet potato mild mottle virus (SPMMV), Sweet potato latent virus (SPLV), Sweet potato chlorotic fleck virus (SPCFV), Sweet potato mild speckling virus (SPMSV), C-6 virus, Sweet potato chlorotic stunt virus (SPCSV), and Sweet potato caulimovirus (SPCaLV) using a nitrocellulose membrane enzyme-linked immunosorbant assay (NCM-ELISA) kit provided by the International Potato Center (CIP) in Peru. The presence of each virus was indicated when the membrane showed purple color, as recommended by the kit. Newly characterized potyviruses infecting sweetpotato in the United States, including Sweet potato virus G (SPVG) and Ipomoea vein mosaic virus (IVMV), (Moyer et al., 2002; Souto et al., 2003) may have also been in the plots; however, reliable testing procedures for these new viruses were not available during this study.

STATISTICAL ANAlysis. To compare effects of generation on yield and storage root quality per year, the data were analyzed as a split plot with location as the main plot factor and clone and generation as subplot factors. Residual analysis was conducted to determine normality of data and homogeneity of variances (SAS, 1998). For 1999, yields of graded storage roots and measurements of storage root quality for each generation were analyzed using the SAS's general linear models (GLM) procedure (SAS Institute, 1998) to adjust for data lost in two plots in Clinton and one plot in Kinston due to flooding caused by Hurricane Floyd. The least squares means (LSMEANS) procedure was used to compare generations of each clone at alpha levels 0.05 and 0.1. For 2000 and 2001, yields of graded storage roots and measurements of storage root quality for each generation were analyzed using the SAS analysis of variance (ANOVA) procedure (SAS Institute, 1998). Fisher's protected least significant difference (LSD) was used to compare generations of each clone at alpha levels 0.05 and 0.1 . For comparisons of the generations to 'Beauregard' stock, a separate analysis was conducted for each year (GLM for 1999 and ANOVA for 2000 and 2001), where each clone and generation was analyzed as separate treatments. The analysis used comparisons of LSMEANS for 1999 data and Fisher's protected LSD for 2000 and 2001 data for comparison at alpha levels 0.05 and 0.1 .

In order to construct predictive models for yield and root quality measurements over seed generations, a linear regression analysis was conducted using the SAS Regression (REG) procedure (SAS Institute, 1998). G1 yield and storage root quality measurements of B94-14 and B94-34, and the yield and storage root quality measurements of storage roots produced from the subsequent adventitious propagules (G2-G5) derived from the original G1 plant material were used in the analysis. Thus, a total of three sets of data were analyzed: G1-G5 (1997-2001), G1-G4 (1998-2001), and G1-G3 (1999-2001). In order to account for year effects, the ratio of yield and storage root quality measurements of the generations, G2-G5, to the yield and storage root quality measurements of the G1 grown the same year was used in the regression. Because the G2 and G3 of 1999, G3 and G4 of 2000, and G4 and G5 of 2001 were derived from the G1 material

Table 2. Statistical differences detected for sweetpotato yield and storage root quality measurements for each source of variation. ${ }^{2}$

\begin{tabular}{|c|c|c|c|c|c|c|c|c|c|c|}
\hline \multirow{3}{*}{$\begin{array}{l}\text { Source of } \\
\text { variation }\end{array}$} & \multirow{2}{*}{\multicolumn{7}{|c|}{ Yield $\left(\mathrm{kg} \cdot \mathrm{ha}^{-1}\right)$}} & \multicolumn{3}{|c|}{ Root quality } \\
\hline & & & & & & & & \multirow{2}{*}{$\begin{array}{c}\text { Shape } \\
\text { uniformity }\end{array}$} & \multirow{2}{*}{$\begin{array}{l}\mathrm{L} / \mathrm{D} \\
\text { ratio }\end{array}$} & \multirow{2}{*}{$\begin{array}{c}\text { Overall } \\
\text { appearance }\end{array}$} \\
\hline & Total & TMY & No. 1 & Canners & Jumbos & Culls & No. $1(\%)$ & & & \\
\hline \multicolumn{11}{|l|}{1999} \\
\hline Site $(\mathrm{S})$ & $* * *$ & $* * *$ & $* * * *$ & $* * *$ & $* * * *$ & $* * *$ & $* * *$ & NS & $* * *$ & $* *$ \\
\hline Replication (site) & $* * * *$ & $* * * *$ & $* * *$ & $*$ & NS & $* *$ & $* *$ & NS & $* * *$ & NS \\
\hline Clone $(\mathrm{C})$ & NS & $*$ & $*$ & NS & NS & NS & $*$ & NS & $* *$ & NS \\
\hline Generation (G) & NS & NS & $*$ & $*$ & NS & $*$ & $*$ & $*$ & $* *$ & NS \\
\hline $\mathrm{C} \times \mathrm{G}$ & NS & NS & NS & NS & NS & NS & NS & NS & $*$ & NS \\
\hline $\mathrm{S} \times \mathrm{C}$ & NS & NS & NS & NS & NS & NS & NS & $*$ & NS & $* * *$ \\
\hline $\mathrm{S} \times \mathrm{G}$ & $* * *$ & $* * *$ & $* * *$ & NS & $* * *$ & NS & $* * *$ & $* *$ & $* *$ & $* * *$ \\
\hline $\mathrm{S} \times \mathrm{C} \times \mathrm{G}$ & $* *$ & $* *$ & $*$ & NS & $*$ & NS & NS & NS & NS & $* *$ \\
\hline \multicolumn{11}{|l|}{2000} \\
\hline S & NS & NS & $* * *$ & $* * * *$ & $* * *$ & NS & $* * * *$ & $*$ & $* * * *$ & NS \\
\hline Replication (site) & $* * *$ & $* * *$ & $* *$ & NS & NS & $* * * *$ & $* *$ & NS & NS & $*$ \\
\hline $\mathrm{C}$ & NS & NS & NS & NS & $*$ & $*$ & NS & NS & $*$ & NS \\
\hline G & $*$ & $*$ & $*$ & NS & NS & $* *$ & $*$ & $* *$ & $* * *$ & $* * *$ \\
\hline $\mathrm{C} \times \mathrm{G}$ & NS & NS & NS & NS & $* *$ & NS & NS & NS & NS & NS \\
\hline $\mathrm{S} \times \mathrm{C}$ & NS & NS & NS & $* *$ & NS & NS & NS & $* *$ & NS & NS \\
\hline $\mathrm{S} \times \mathrm{G}$ & NS & NS & $* * *$ & $* * * *$ & $* *$ & NS & $* *$ & $* *$ & $* *$ & $*$ \\
\hline $\mathrm{S} \times \mathrm{C} \times \mathrm{G}$ & NS & NS & NS & $*$ & NS & NS & NS & NS & NS & NS \\
\hline \multicolumn{11}{|l|}{2001} \\
\hline $\mathrm{S}$ & $* * * *$ & $* * * *$ & $* * * *$ & $* * *$ & $* * * *$ & $* * * *$ & $* * * *$ & $* * *$ & $* * *$ & $* * * *$ \\
\hline Replication (site) & $* * *$ & $* *$ & $* *$ & $*$ & NS & $* *$ & $* * *$ & $* * *$ & NS & $* * * *$ \\
\hline $\mathrm{C}$ & NS & NS & NS & NS & NS & NS & NS & $*$ & NS & NS \\
\hline G & $* * *$ & $* * *$ & $* * *$ & NS & NS & NS & $* * *$ & $* * *$ & $* * *$ & $* * * *$ \\
\hline $\mathrm{C} \times \mathrm{G}$ & NS & NS & NS & NS & $*$ & NS & NS & NS & NS & NS \\
\hline $\mathrm{S} \times \mathrm{C}$ & NS & NS & $* *$ & NS & $*$ & NS & NS & NS & $* *$ & NS \\
\hline $\mathrm{S} \times \mathrm{G}$ & NS & NS & $* * *$ & $* * * *$ & NS & $*$ & $* * *$ & $*$ & $* * *$ & NS \\
\hline $\mathrm{S} \times \mathrm{C} \times \mathrm{G}$ & $*$ & NS & NS & NS & NS & NS & NS & NS & NS & NS \\
\hline
\end{tabular}

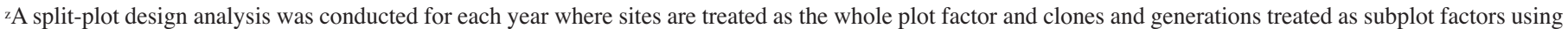
the general linear model procedure for 1999 and analysis of variance for 2000 and 2001 (SAS, 1998).

ns, $, * * * * * *, * * * *$ Nonsignificant or significant at $P \leq 0.1,0.05,0.01$, or 0.001 , respectively. 
initially used in 1997 and 1998, data from these years are included in the analysis. These data have been previously reported in the 1997 and 1998 North Carolina Sweetpotato Progress Reports. An ANOVA test was conducted to determine equality of slopes for the ratios of each clone and generational line for the yield and storage root quality measurements that were significant when comparing generations within each year.

\section{Results}

IMPACT OF GENERATIONS ON SWEETPOTATO YIELD AND QUALITY. 1999. Differences were detected $(p=0.1)$ for locations, clones and generations, and their interactions, for yield and storage root quality measurements when comparing generations of clones B9414 and B94-34 (Table 2). The effect of generation was significant for yield of No. 1s, canners, culls, percent No. 1s, uniformity, and $\mathrm{L} / \mathrm{D}$ ratio (Table 2). The rank of mean yield and storage root quality measurements for generation for total yield, TMY, No. 1s, culls, percent No. 1s, shape uniformity, L/D ratio, and overall appearance were generally consistent across locations (data not shown). Thus, mean yield for each clone and respective generation averaged across locations are reported in Table 3. No. 1 yield of B94-34 G1 was higher than B94-34 G3. Yield of culls of B94-34
G1 was lower than B94-34 G2 while yield of culls of B94-14 G1 was lower than B94-14 G2 and G3. Shape uniformity of G1 storage roots of both clones was higher than G2 or G3 storage roots. Percent No. 1 yields of G1, G2, and G3 decreased as the number of generations in the field increased for B94-34 while percent No. 1 yields of B94-14 decreased in G3 compared with $\mathrm{G} 1$. L/D ratios of $\mathrm{G} 1$ storage roots were lower than both $\mathrm{G} 2$ and G3 storage roots in both B94-14 and B94-34.

For the analysis comparing generations of clones to unimproved 'Beauregard,' differences were detected $(p \leq 0.10)$ in total yield, TMY, No. 1s, culls, percent No. 1s, uniformity, and $\mathrm{L} / \mathrm{D}$ ratio. G1 storage root yields were higher for both clones in total yield, TMY, and yield of No. 1s than 'Beauregard' (Table 3). B94-14 G1 produced a higher percentage of No. 1 roots and fewer cull roots than 'Beauregard.' Root quality measurements of shape uniformity in B94-14 and B94-34 G1 were higher than 'Beauregard.' L/D ratios of B94-14 and B94-34 G1 were lower than 'Beauregard.'

2000. As observed for 1999, significant differences were detected $(p=0.1)$ among the main effects and first order interactions for both yield and storage root quality measurements for generations (Table 2). The effects of generation were significant for total yield, TMY, No. 1s, culls, percent No. 1s, shape uniformity, L/D

Table 3. Sweetpotato yield and storage root quality measurements recorded for each clone and respective generation in 1999, 2000, and $2001 .{ }^{\mathrm{z}}$

\begin{tabular}{|c|c|c|c|c|c|c|c|c|c|}
\hline \multirow[b]{3}{*}{ Year } & \multirow[b]{3}{*}{ Sourcey } & \multirow{2}{*}{\multicolumn{5}{|c|}{ Yield $\left(\mathrm{kg} \cdot \mathrm{ha}^{-1}\right)$}} & \multicolumn{3}{|c|}{ Root quality } \\
\hline & & & & & & & \multirow{2}{*}{$\begin{array}{c}\text { Shape } \\
\text { uniformity }\end{array}$} & \multirow{2}{*}{$\begin{array}{l}\mathrm{L} / \mathrm{D} \\
\text { ratio }\end{array}$} & \multirow{2}{*}{$\begin{array}{c}\text { Overall } \\
\text { appearance }\end{array}$} \\
\hline & & Total & TMY & No.1s & Culls & No.1 (\%) & & & \\
\hline \multirow[t]{5}{*}{1999} & B94-14 G1 & $26.2 \mathrm{~A}^{\mathrm{x}} \mathrm{a}^{* *}$ & $25.4 \mathrm{~A} \mathrm{a}^{* *}$ & $16.2 \mathrm{~A} \mathrm{a}^{* *}$ & $0.7 \mathrm{~A} \mathrm{a}^{*}$ & $62 \mathrm{~A} \mathrm{a}^{*}$ & $3.0 \mathrm{~A} \mathrm{a}^{*}$ & $2.5 \mathrm{~A} \mathrm{a}^{* * *}$ & $2.9 \mathrm{~A} \mathrm{a}$ \\
\hline & B94-14 G3 & $24.9 \mathrm{~A} \mathrm{a}^{*}$ & $23.3 \mathrm{~A} \mathrm{a}$ & $14.3 \mathrm{~A} \mathrm{a}$ & $1.6 \mathrm{AB} \mathrm{b}$ & $55 \mathrm{Ab}$ & $2.9 \mathrm{~A} \mathrm{ab}$ & $3.0 \mathrm{~B} \mathrm{~b}$ & $2.6 \mathrm{Aa}$ \\
\hline & B94-34 G1 & $25.4 \mathrm{~A} \mathrm{a}^{*}$ & $24.3 \mathrm{~A} \mathrm{a}^{*}$ & $15.5 \mathrm{~A} \mathrm{a}^{*}$ & $1.1 \mathrm{~A} \mathrm{a}$ & $58 \mathrm{~A} \mathrm{a}$ & $3.0 \mathrm{~A} \mathrm{a}^{* *}$ & $2.8 \mathrm{~A} \mathrm{a}^{*}$ & $2.9 \mathrm{Aa}$ \\
\hline & B94-34 G2 & $23.4 \mathrm{~A} \mathrm{a}$ & $21.9 \mathrm{~A} \mathrm{a}$ & $13.6 \mathrm{~A} \mathrm{ab}$ & $1.6 \mathrm{Ab}$ & $57 \mathrm{Ab}$ & $2.8 \mathrm{Ab}$ & $3.0 \mathrm{Ab}$ & $2.7 \mathrm{~A} \mathrm{a}$ \\
\hline & Beauregard & 21.4 & 20.0 & 12.6 & 1.4 & 55 & 2.6 & 3.1 & 2.5 \\
\hline \multirow[t]{5}{*}{2000} & B94-14 G1 & $34.8 \mathrm{~A} \mathrm{a}$ & $33.8 \mathrm{~A} \mathrm{a}$ & $23.3 \mathrm{~A} \mathrm{a}^{*}$ & $1.0 \mathrm{~A} \mathrm{a}^{* *}$ & $65 \mathrm{~A} \mathrm{a}^{* *}$ & $3.4 \mathrm{~A} \mathrm{a}^{* *}$ & $2.4 \mathrm{~A} \mathrm{a}^{* *}$ & $3.5 \mathrm{~A} \mathrm{a}^{* *}$ \\
\hline & B94-14 G2 & $33.1 \mathrm{~A} \mathrm{ab}$ & $30.9 \mathrm{AB} a b$ & $20.5 \mathrm{~A} \mathrm{ab}$ & $2.3 \mathrm{~B} \mathrm{~b}$ & $61 \mathrm{Aa}$ & $2.9 \mathrm{~A} \mathrm{ab}$ & $3.0 \mathrm{~B} \mathrm{~b}^{* *}$ & $2.6 \mathrm{~B} \mathrm{~b}$ \\
\hline & B94-14 G3 & $30.9 \mathrm{~A} \mathrm{~b}$ & $28.8 \mathrm{~B} \mathrm{~b}$ & $18.7 \mathrm{Ab}$ & $2.0 \mathrm{~B} \mathrm{~b}$ & $59 \mathrm{~A} \mathrm{a}$ & $2.9 \mathrm{Ab}$ & $3.1 \mathrm{~B} \mathrm{bc}$ & $2.3 \mathrm{~B} \mathrm{~b}$ \\
\hline & B94-14 G4 & $32.7 \mathrm{~A} \mathrm{ab}$ & $30.7 \mathrm{AB} a b$ & $19.9 \mathrm{Ab}$ & $2.0 \mathrm{~B} \mathrm{~b}$ & $60 \mathrm{~A} \mathrm{a}$ & $2.9 \mathrm{Ab}$ & $3.3 \mathrm{~B} \mathrm{c}$ & $2.3 \mathrm{~B} \mathrm{~b}$ \\
\hline & B94-34 G1 & $38.5 \mathrm{~A} \mathrm{a}^{* *}$ & $37.6 \mathrm{~A} \mathrm{a}^{*}$ & $25.9 \mathrm{~A} \mathrm{a}^{* *}$ & $0.8 \mathrm{~A} \mathrm{a}^{* *}$ & $67 \mathrm{~A} \mathrm{a}^{* *}$ & $3.4 \mathrm{~A} \mathrm{a}^{* *}$ & $2.6 \mathrm{~A} \mathrm{a}^{* *}$ & $3.6 \mathrm{~A} \mathrm{a}^{* *}$ \\
\hline \multirow[t]{11}{*}{2001} & B94-14 G1 & $35.3 \mathrm{~A} \mathrm{a}^{* *}$ & $33.4 \mathrm{~A} \mathrm{a}^{* *}$ & $21.6 \mathrm{~A} \mathrm{a}^{* *}$ & $1.9 \mathrm{~A} \mathrm{a}$ & $61 \mathrm{~A} \mathrm{a}^{* *}$ & $3.3 \mathrm{~A} \mathrm{a}^{* *}$ & $2.7 \mathrm{~A} \mathrm{a}^{* *}$ & $3.4 \mathrm{~A} \mathrm{a}^{* *}$ \\
\hline & B94-14 G2 & $30.9 \mathrm{~B} \mathrm{~b}$ & $29.2 \mathrm{~B} \mathrm{~b}$ & $16.1 \mathrm{BC} \mathrm{b}$ & $1.7 \mathrm{~A} \mathrm{a}$ & $52 \mathrm{BC} \mathrm{b}$ & $2.8 \mathrm{~B} \mathrm{~b}$ & $3.2 \mathrm{~B} \mathrm{~b}$ & $2.5 \mathrm{~B} \mathrm{c}$ \\
\hline & B94-14 G3 & 29.8 B b & $27.9 \mathrm{~B} \mathrm{~b}$ & $16.2 \mathrm{AB} b$ & $1.9 \mathrm{~A} \mathrm{a}$ & $54 \mathrm{AB} b$ & $2.9 \mathrm{AB} \mathrm{b}$ & $3.2 \mathrm{~B} \mathrm{~b}$ & $2.7 \mathrm{~B} \mathrm{~b}$ \\
\hline & B94-14 G4 & $31.9 \mathrm{~B} \mathrm{ab}$ & $29.6 \mathrm{~B} \mathrm{~b}$ & $16.3 \mathrm{BC} b c$ & $2.3 \mathrm{Aa}$ & $46 \mathrm{BC} \mathrm{bc}$ & $2.8 \mathrm{~B} \mathrm{~b}$ & $3.3 \mathrm{~B} \mathrm{~b}$ & $2.6 \mathrm{~B} \mathrm{bc}$ \\
\hline & B94-14 G5 & $31.1 \mathrm{~B} \mathrm{~b}$ & $29.0 \mathrm{~B} \mathrm{~b}$ & $14.5 \mathrm{C} \mathrm{c}$ & $2.2 \mathrm{~A} \mathrm{a}$ & $49 \mathrm{C} \mathrm{c}^{*}$ & $2.9 \mathrm{AB} b$ & $3.4 \mathrm{~B} \mathrm{~b}$ & $2.5 \mathrm{~B} \mathrm{c}$ \\
\hline & B94-34 G1 & $37.1 \mathrm{~A} \mathrm{a}^{* *}$ & $35.5 \mathrm{~A} \mathrm{a}^{* *}$ & $23.7 \mathrm{~A} \mathrm{a}^{* *}$ & $1.6 \mathrm{~A} \mathrm{a}$ & $65 \mathrm{~A} \mathrm{a}^{* *}$ & $3.6 \mathrm{~A} \mathrm{a}^{* *}$ & $2.7 \mathrm{~A} \mathrm{a}^{* *}$ & $3.4 \mathrm{~A} \mathrm{a}^{* *}$ \\
\hline & B94-34 G2 & $31.0 \mathrm{~B} \mathrm{~b}$ & $28.8 \mathrm{~B} \mathrm{~b}$ & $16.1 \mathrm{~B} \mathrm{~b}$ & $2.2 \mathrm{AB} a \mathrm{~b}$ & $52 \mathrm{~B} \mathrm{~b}$ & $3.0 \mathrm{~B} \mathrm{~b}$ & $3.2 \mathrm{~B} \mathrm{~b}$ & $2.8 \mathrm{~B} \mathrm{~b}$ \\
\hline & B94-34 G3 & $31.7 \mathrm{~B} \mathrm{~b}$ & $28.9 \mathrm{~B} \mathrm{~b}$ & $15.9 \mathrm{~B} \mathrm{~b}$ & $2.8 \mathrm{~B} \mathrm{c}^{* *}$ & $52 \mathrm{~B} \mathrm{~b}$ & $2.8 \mathrm{~B} \mathrm{~b}$ & $3.2 \mathrm{~B} \mathrm{~b}$ & $2.6 \mathrm{BC} \mathrm{bc}$ \\
\hline & B94-34 G4 & $30.4 \mathrm{~B} \mathrm{~b}$ & $27.9 \mathrm{~B} \mathrm{~b}$ & $15.8 \mathrm{~B} \mathrm{~b}$ & $2.5 \mathrm{~B} \mathrm{bc}^{*}$ & $50 \mathrm{~B} \mathrm{~b}$ & $2.9 \mathrm{~B} \mathrm{~b}$ & $3.1 \mathrm{~B} \mathrm{~b}$ & $2.5 \mathrm{BC} \mathrm{c}$ \\
\hline & B94-34 G5 & $30.0 \mathrm{~B} \mathrm{~b}$ & $27.4 \mathrm{~B} \mathrm{~b}$ & $14.5 \mathrm{~B} \mathrm{~b}$ & $2.2 \mathrm{AB} a b$ & $48 \mathrm{~B} \mathrm{~b}$ & $2.9 \mathrm{~B} \mathrm{~b}$ & $3.3 \mathrm{~B} \mathrm{~b}$ & $2.3 \mathrm{C} \mathrm{c}^{*}$ \\
\hline & Beauregard & 31.2 & 29.8 & 16.6 & 1.5 & 53 & 2.9 & 3.3 & 2.6 \\
\hline
\end{tabular}

zYield and storage root quality values are the means of five replications, 25 plants per plot, averaged over sites in each year.

yMericlones B94-14 and B94-34 represent micropropagated, improved selections of the nonmicropropagated 'Beauregard.' The terms G1 to G5 represents number of years in field production.

xMean separation within columns by Fisher's protected LSD $\square P \leq 0.05$ (uppercase letters) and $P \leq 0.1$ (lowercase letters) comparing generations of each mericlone in each year. Columns with the same upper or lower case letter are not significantly different.

****Mean separation within columns by Fisher's protected LSD $\square P \leq 0.05$ or 0.1 , respectively, comparing each clone and respective generation to NCSU 'Beauregard' in each year. 

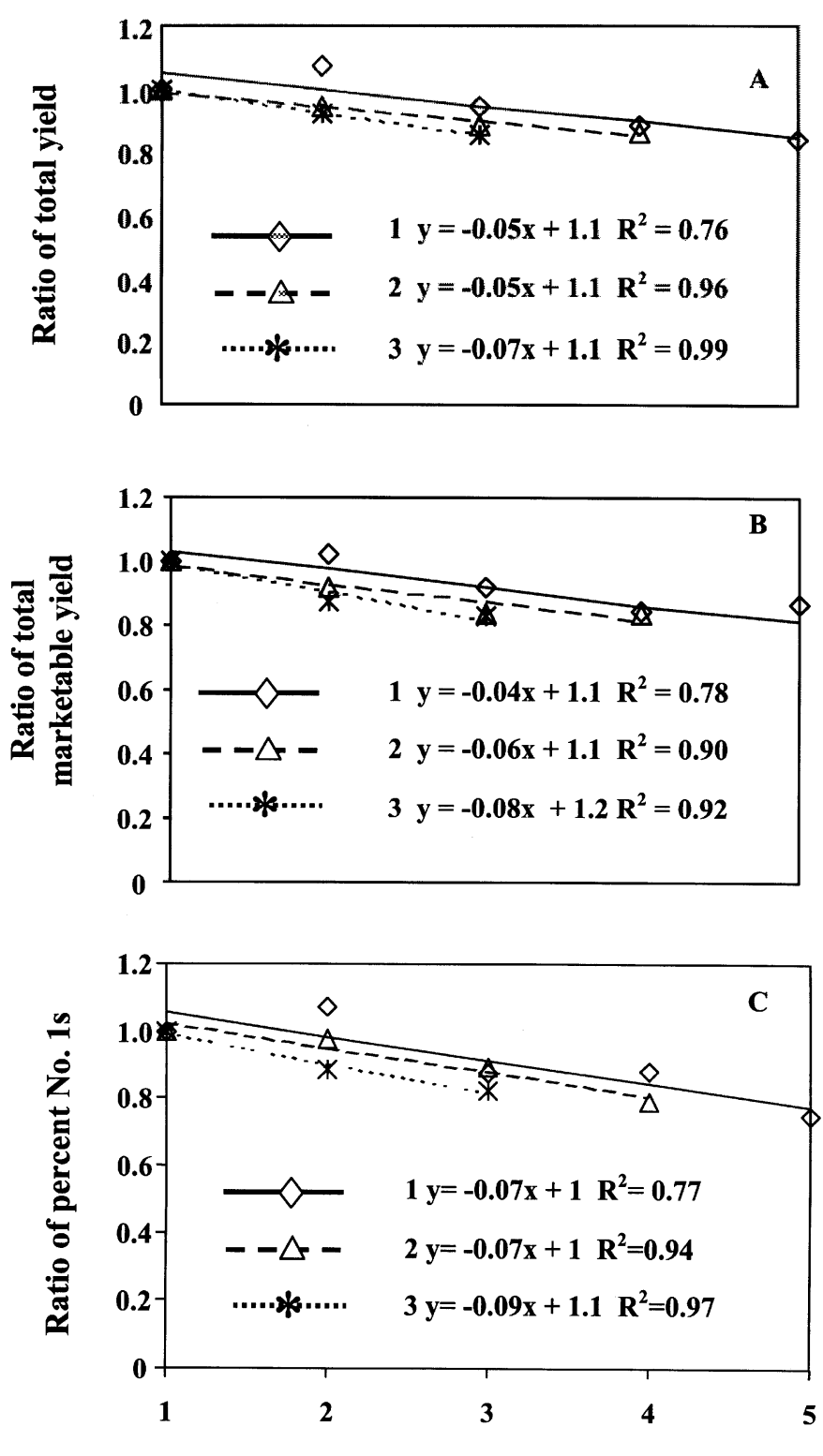

Years in field production

Fig. 1. Predictive models for decline in yield of the improved 'Beauregard' sweetpotato mericlones B94-14 and B94-34. Yields were averaged across mericlones and locations each year. Yield of micropropagated, virus-tested, greenhouse produced, $\mathrm{G} 1$ nodal cuttings ( $\mathrm{G}$ represents generation while the number indicates the number of years in field production) of B94-14 and B9434 , and the yield of storage roots produced from the subsequent adventitious propagules (G2-G5) derived from the original G1 plant material were used in the analyses. The ratio is expressed as the mean yield of the generations to the yield of the G1 grown the same year. Regression line $1=$ yield measurements recorded for G1-G5 (1997-2001); regression line 2 = yield measurements recorded for G1-G4 (1998-2001); regression line 3 = yield measurements recorded for G1-G3 (1999-2001); $y=$ predicted yield expressed as the percentage of the yield of each subsequent generation (G2-G5) relative to the G1 yield of the same year; and $\mathrm{x}=$ number of years in field production.

ratio, and overall appearance. As observed in 1999, the rank of most traits at each location was generally consistent for mean yield and storage root quality measurements averaged over locations (data not shown); therefore, mean yield and storage root quality for each clone and respective generation were averaged over locations (Table 3). In 2000, B94-14 G1 plants produced higher total yield and TMY than B94-14 G3 plants while B94-34 G1
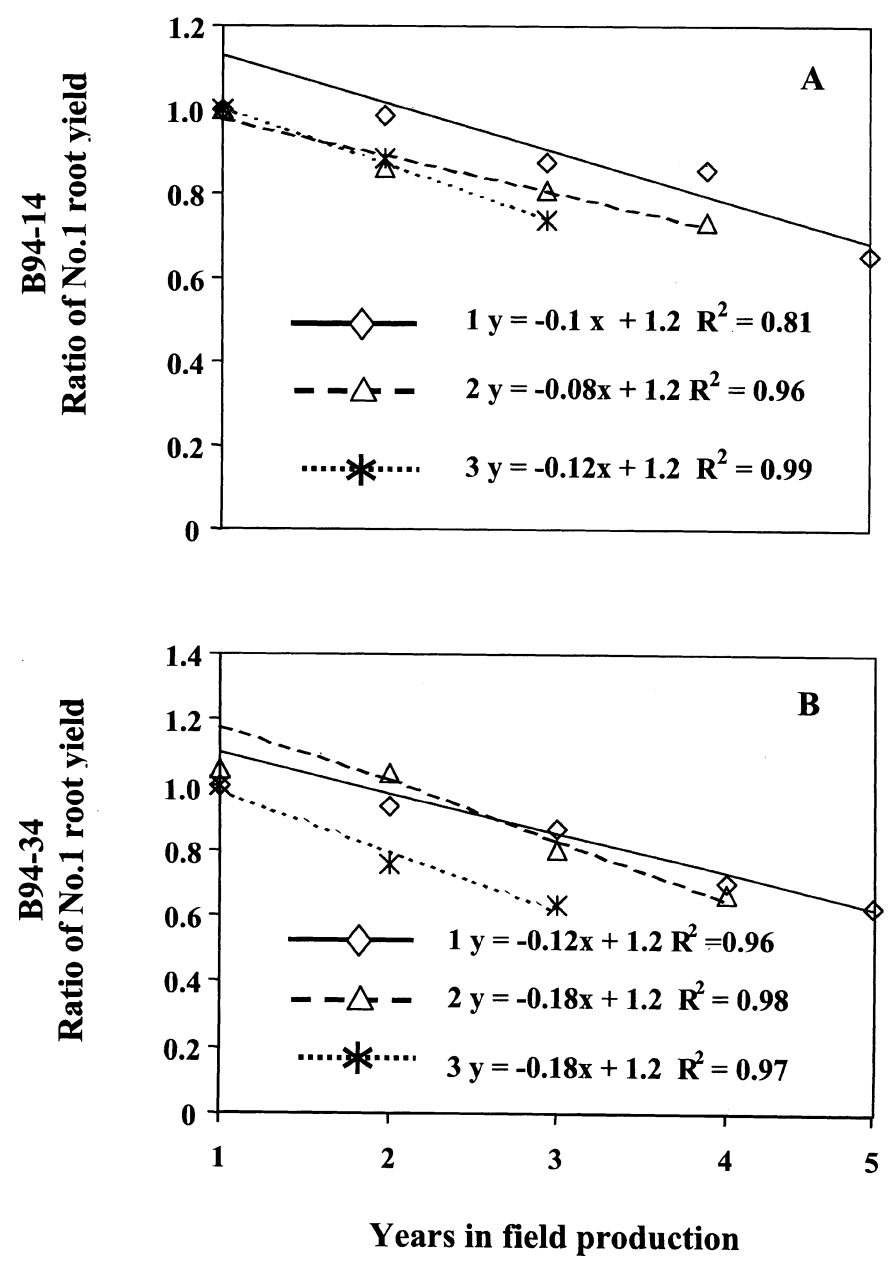

Fig. 2. Predictive models for decline in No.1 root yield of improved 'Beauregard' sweetpotato mericlones B94-14 and B94-34. No. 1 root yields were averaged for each mericlone over locations. No.1 root yields of micropropagated, virustested, greenhouse produced, G1 nodal cuttings (G represents generation while the number indicates the number of years in field production) of each B94-14 and B94-34, and the yield measurements of storage roots produced from the subsequent adventitious propagules (G2-G5) derived from the original G1 plant material of each mericlone were used in the analyses. The ratio is expressed as the mean No.1 root yield of the generations to the No.1 root yield of the G1 grown the same year. Regression line $1=$ No.1 root yield recorded for G1-G5 (1997-2001); regression line 2 = No.1 root yield recorded for G1-G4 (19982001); regression line 3 = No.1 root yield recorded for G1-G3 (1999-2001); y $=$ predicted No.1 root yield expressed as the percentage of the No.1 root yield of each subsequent generation (G2-G5) relative to the G1 No.1 root yield of the same year; and $\mathrm{x}=$ number of years in field production.

plants produced higher total yield than B94-34 G4 plants. No. 1 root yields of G1 plants were higher than No. 1 root yields of G4 plants for both mericlones. G1 plants also yielded more No. 1 roots than G3 plants derived from B94-14 and G2 plants obtained from B94-34. Cull yields of G1 plants of both clones were lower than all other generations (G2-G4). The percent No. 1 yield produced by B94-34 G1 plants was higher than that produced by G2 and G4 plants, while no statistical differences were detected with B94-14. Shape uniformity and overall appearance ratings for G1 in storage roots of both clones were higher than all other generations, with one exception, and L/D ratios for G1 storage roots of both clones were lower than all other generations.

For the analysis comparing clones and generations to 'Beauregard', significant differences were found between all yield and storage root quality measurements of 'Beauregard' B94-34 

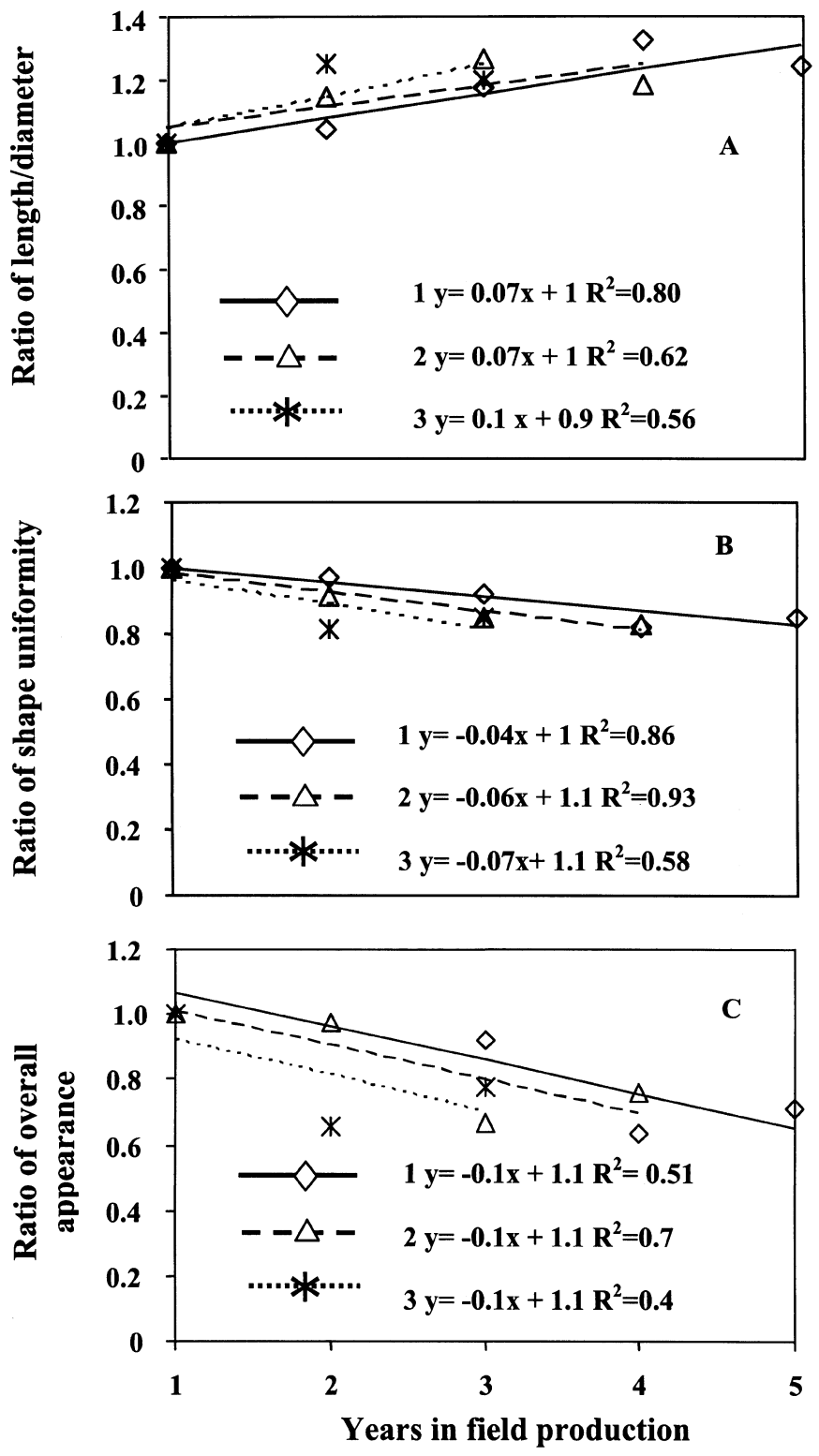

Fig. 3. Predictive models for decline in storage root quality of improved 'Beauregard' sweetpotato mericlones B94-14 and B94-34. Storage root quality measurements were averaged over mericlones and locations each year. Storage root quality measurements of micropropagated, virus-tested, greenhouse produced, G1 nodal cuttings (G represents generation while the number indicates the number of years in field production), and the root quality measurements of roots produced from the subsequent adventitious propagules (G2-G5) derived from the original G1 plant material were used in the analysis. The ratio is expressed as the mean root quality measurements of the generations to the root quality measurements of the G1 grown the same year. Regression line $1=$ root quality measurements recorded for G1-G5 (1997-2001); regression line $2=$ root quality measurements recorded for G1-G4 (1998-2001); regression line 3 = root quality measurements recorded for G1-G3 (1999-2001); y = predicted root quality expressed as the percentage of the root quality measurement of each subsequent generation (G2-G5) relative to the G1 root quality measurement of the same year; and $\mathrm{x}=$ number of years in field production.

G1 and all storage root quality measurements for 'Beauregard' B94-14 G1. B94-34 G1 plants yielded higher than 'Beauregard' in total yield, TMY, No. 1 yield, and percent No. 1s. B94-14 G1 plants produced higher yields of No. $1 \mathrm{~s}$ and percent No. $1 \mathrm{~s}$ than 'Beauregard'. Both B94-14 G1 and B94-34 G1 had lower cull yields and L/D ratios, and better shape uniformity and overall appearance ratings than 'Beauregard.' L/D ratios of B94-14 G2 were lower than 'Beauregard.' B94-14 and B94-34 G2-G4 were not significantly different from 'Beauregard' in any other measurements recorded (Table 3 ).

2001. As observed in 1999 and 2000, significant differences were detected ( $p=0.1$ ) among main effects and first-order interactions for both yield and storage root quality measurements for generations (Table 2). Effects of generation were significant for total yield, TMY, yield of No. 1s, percent No. 1s, shape uniformity, L/D ratio, and overall appearance (Table 2). Again, mean yield and storage root quality measurements for each clone and respective generation at each location were generally consistent with mean yield and storage root quality measurements averaged over locations (Table 3). In 2001, G1 plants produced higher total, TMY, yield of No. 1s, and percent No. 1s for both clones compared with all other generations (Table 3). B94-14 G5 plants produced lower No. 1 yields and percent No. 1s than B94-14 G1, G2, and G3. G1 storage roots had higher shape uniformity ratings and lower L/D ratios when compared with all other generations for both clones. The overall appearance rating of B94-34 G1 storage roots was higher than all other generations with a gradual decline in appearance from G1-G5.

When clones and generations were compared to 'Beauregard', significant differences were found between G1 storage roots of both clones for all yield measurements except cull yields and all storage root quality measurements. Total yield, TMY, yield of No. $1 \mathrm{~s}$, and percent No. 1s and storage root quality measurements of uniformity and appearance ratings for G1 B94-14 and B94-34 were higher than 'Beauregard'. L/D ratios of G1 storage roots of both clones were lower than 'Beauregard.' Overall ratings of B94-34 G5 storage roots were lower and yield of culls of B94-34 G3 and B94-34 G4 were higher than 'Beauregard.'

REGRESSION ESTIMATES OF GENERATION ON SWEETPOTATO YIELD AND QUALITY. The ANOVA to test equality of slopes indicated that the rate of reduction in No. 1 yields differed between clones B9414 and B94-34 for G1-G4 (1998-2001) and G1-G3 (1999-2001). Therefore, linear regression analysis was conducted separately for each for No. 1 yield. For all other significant yield and storage root quality measurements, linear regression equations were determined by combining data from both clones. The combined linear regression analyses over clones indicated that total yield, TMY, and percent No. 1s decline as generation number increases (Fig. 1). The percent decrease in yield (slope of regression equation) was $\approx 5 \%$ for total yield, $4 \%$ for TMY, and $7 \%$ for percent No. 1s. The linear regression analysis indicates that the rate of decrease of yield of No. 1s is higher in B94-34 than B94-14 with the rate of yield decrease for B94-34 estimated to be between $12 \%$ and $18 \%$ and ranging between $8 \%$ and $12 \%$ for B94-14 (Fig. $2)$. For the second and third generational lines analyzed (G1-G4 and G1-G3, respectively), R-square values were at least 0.90 for total yield, TMY, yield of No. 1s, and percent No. 1s, indicating that at least $90 \%$ of the decline in each trait could be predicted by seed generation. Linear regression analysis also indicated that $\mathrm{L} / \mathrm{D}$ ratio increases with generation, and overall appearance and shape uniformity decrease with clonal generation (Fig. 3).

VIRUS MONITORING. Both years of virus monitoring indicated that all plant sources became infected with virus during the growing season. In $2000,<2 \%$ of G1 plants and at least $30 \%$ of G2-G5 and 'Beauregard' plants displayed foliar symptoms of virus 4 WAP. By 5 WAP, the percentage of virus symptomatic plants increased by $\approx 40 \%$ in all clones, and the majority of G2-G5 plants were displaying symptoms of virus. By 10 WAP, all sweetpotato plants, 
including G1 plants, were displaying symptoms of virus. In 2001, $\approx 10 \%$ of G1 plants and at least $90 \%$ of G2-G5 plants and 'Beauregard' displayed symptoms of virus 1 WAP. All G2-G5 plants and 'Beauregard' displayed virus symptoms by 5 WAP while all G1 plants displayed virus symptoms by 8 WAP.

All plants sampled for grafting on the indicator plant I. setosa indicated the presence of SPFMV. When using only selected $I$. setosa grafts with severe symptoms, NCM-ELISA confirmed the presence of SPFMV. Tests using NCM-ELISA for the presence of SPCSV, SPMMV, SPLV, SPCFV, SPMSV, C-6 virus, SPCSV, and SPCaLV yielded negative results suggesting that these viruses were not present in the samples. Tests for SPVG and IVMV were not available.

\section{Discussion}

Sweetpotato is a notoriously variable crop with storage root yield and quality being sensitive to a wide range of environmental variations (Bacusmo et al., 1988; Carpena et al., 1982; Collins et al., 1987; Kannua and Floyd, 1988; Ngeve and Bouwkamp, 1993). The significant generation $\times$ location, and clone $\times$ location interactions observed in this study can be partially attributed to yearly environmental differences and variations in cultural practices used for on-farm and research station trials. However, the consistently high yield and storage root quality achieved through the use of G1 plants is likely due to the increased genetic uniformity and quality of micropropagated planting materials, and the absence of virus in those materials before planting. Micropropagation and virus-indexing of meristemed clones (mericlones) provides material free of known viruses that can be rapidly multiplied for planting stock via nodal cuttings of mericlones and greenhouse increase. In a companion study, Bryan (2002) found that yield and quality of micropropagated G1 seed infected with virus before planting was reduced compared to virus-tested G1 planting materials. Previous reports have also indicated that adventitious propagules of sweetpotato derived from sprouts of storage roots are genetically more variable than those produced from preexisting meristematic regions, such as micropropagated plants (Villordon and LaBonte, 1996). This variability presumably alters favorable genetic combinations, resulting in deleterious mutations that may lead to decline (Villordon and LaBonte, 1996). We found that significant differences in sweetpotato yield and storage root quality could be observed in plantings of G2-G5 seed derived from adventitious propagules compared to micropropagated G1 planting materials produced via meristematic propagation. The relative importance of SPFMV and other potyviruses, and possible interaction of mutations in cultivar decline could not be ascertained in this study, but these are clearly important sweetpotato seed production issues that need to be investigated.

The cultivar decline we observed in this study appears to occur gradually. This was expected as it has been previously shown in several plant species that decreased plant vigor and yield result from a gradual accumulation of deleterious mutations over time, a phenomenon termed Muller's Rachet (Muller, 1964). Generally, significant differences were observed between micropropagated G1 and adventitious G2-G5 planting stock for most mean yield and storage root quality measurements. Differences observed among G2-G5 planting stock were more subtle and less consistent, with no consistent differences being observed between adventitiously derived planting stock (i.e., G2, G3, etc.) in most mean yield and storage root quality measurements until after four generations of adventitious propagation (i.e., G5). For example, in comparing B94-14 and B94-34 with 'Beauregard,' consistent statistical differences in percent No. 1s and overall appearance were not observed until after five propagation cycles (G5). We do not know why the 'Beauregard', which has been adventitiously propagated for $>5$ years by the breeding program, performed comparatively well in these tests. It is possible that the 'Beauregard' sweetpotato originally obtained by the breeding program was derived from a more stable clone compared to the study clones. Alternatively, it may be that the true-to-type root selection methods used by the breeding program for the propagation of 'Beauregard' were highly effective, resulting in a more gradual rate of decline. Others have hypothesized that the accumulation of favorable mutations offset deleterious mutations (Haigh, 1978). Thus, true-to-type root selection, which maintains favorable and eliminates deleterious mutations, may further reduce the rate of decline in sweetpotato.

The presence of sweetpotato viruses also undoubtedly contributed to the decline in yield and storage root quality. Symptomless sweetpotato plants and virus-indexed sweetpotato plants have been reported to yield more than virus-infected sweetpotato (Hahn, 1979; Liao et al., 1983; Milgram et al., 1996; Mukiibi, 1977; Ngeve, 1990; Ngeve and Bouwkamp, 1991; Olivero and Oropeza, 1985; Pozzer et al., 1995). Similarly, Kano and Nagata (1999) found SPFMV-infected plants produced storage roots with less weight and lower storage root diameters than storage roots produced from healthy plants. In this study, SPFMV was confirmed to be present in all field generations (G2-G5) after planting in the field. The newly characterized potyviruses infecting sweetpotato in the United States, including SPVG and IVMV (Moyer et al., 2002; Souto et al., 2003), may have also been present; however, reliable testing procedures for these new viruses were not available during this study, so we cannot exclude this possibility. The G2-G5 and 'Beauregard' materials all displayed virus symptoms very early in the growing season indicating that the planting material likely became infected with virus in the previous growing season, or in the field beds used in adventitious propagation. G1 plants became infected with virus by the end of the growing season, indicating that infected sweetpotatoes in field trials or surrounding areas were present. Since G1 plants of both clones produced higher yields and more uniformly shaped storage roots of high quality with a lower $\mathrm{L} / \mathrm{D}$ ratio than all other generations, the presence of virus in transplants may have greater effect on yield and storage root qualities rather than in-season infection. In our experiments, the presence of virus may have caused an increase in the $\mathrm{L} / \mathrm{D}$ ratio of storage roots in G2-G5 storage roots compared to G1 storage roots. Kano and Nagata (1999) also observed that virus-infected plants produced storage roots with smaller diameters than storage roots produced from healthy plants. The decrease in storage root yield of virus-infected G2-G5 plants probably also contributed to the observed decreases in total yield, TMY, yield of No. 1s, and percent No. 1s. A more detailed study of the effects virus have on sweetpotato yield and storage root quality, and the effect of planting virus-infected seed versus noninfected seed that is rapidly infected by virus on yield and quality is reported in a companion study (Bryan et al., 2003).

To better understand the economics of using micropropagated planting material to produce a crop in North Carolina, we conducted a simple profitability analysis for G1 vs. G2-G4 planting material using data provided by three certified seed producers. Presently, cuttings of virus-indexed micropropagated G1 plants are sold for about $\$ 0.20$ /plant, while G2 plants are sold for about $\$ 0.03$ per plant, and lower quality (G4+) seed for $\$ 0.02 /$ plant. 
Using operating and fixed costs for commercial sweetpotato production of $\$ 3967$ and $\$ 619 /$ ha, respectively; and an average price of US No. 1s of \$12.00/18-kg box (Ed Estes, personal communication; North Carolina Dept. of Agriculture and Consumer Services and Louisiana Dept. of Agriculture and Forestry, 2001), and factoring in the costs of plants and No. 1 storage root yields of B94-14 for 2001, we calculated that growers have a potential net return of $\$ 2203 /$ ha for G1 plants, $\$ 5030 /$ ha for G2 plants, and $\$ 4394 /$ ha for G5 plants. Thus, while growers have the potential to produce higher No. 1 yields with G1 plants, a greater monetary return can be achieved using G2 plants because of the high costs associated with producing G1 plants. Further, if growers plant a crop using $\mathrm{G} 2$ seed, they can expect to produce a crop with a higher net return (\$636 per hectare) compared to a crop planted with G5 seed. Based on this analysis, growers should plant their crop using certified G2-G3 seed. Fluctuations in environmental factors and market conditions influencing yield and prices of No. 1 sweetpotato roots, seed costs, etc., will increase or decrease these estimates.

\section{Conclusions}

Viruses rapidly accumulate in sweetpotato through adventitious propagation leading to detectable levels of cultivar decline of 'Beauregard' sweetpotatoes in as few as five generations. In North Carolina, Louisiana, California and China, the use of micropropagation has been found to greatly improve sweetpotato yield and storage root quality (Dangler, 1994; Feng et al., 2000). Sweetpotato micropropagation, accompanied with an effective seed certification program, ensures that high quality planting stock is available for growers. However, further studies are needed to elucidate the possible confounding effects of mutations and virus accumulation leading to cultivar decline. It would also be useful to study decline in other cultivars as our studies suggest that the rate of decline is genotype dependent. Further, development of a better understanding of the relative roles of mutations and viruses in sweetpotato cultivar decline may help breeders develop cultivars that are more stable.

\section{Literature Cited}

Averre, C.W., J.A. Abad, and W.R. Jester. 1993. Sweetpotato virus-free micropropagated Jewel and Beauregard evaluation 1990-1991. Biol. Cult. Tests Control Plant Dis. 8:31.

Bacusmo, J.L., W.W. Collins, and A. Jones. 1988. Comparison of methods of determining stability and adaptation of sweetpotato. Theor. Applied Genet. 75:492-497.

Bryan, A.D. 2002. Impact of Sweet potato feathery mottle virus and micropropagation on yield, root quality, and virus incidence in commercial sweetpotato production systems. MS thesis. N.C. State Univ., Raleigh.

Bryan, A.D., J.S. Schultheis, Z. Pesic-VanEsbroeck, and G.C. Yencho. 2003. Cultivar decline in sweetpotato: II. Impact of virus infection on yield and storage root quality in 'Beauregard' and 'Hernandez' J. Amer. Soc. Hort. Sci. 128:856-863.

Carpena, A.L., E.T. Rebancos, P.H. Manguiat, M.M. Zalmeda, G.E. Sajise, and J.L. San Pedro. 1982. Stability of yield performance of some sweetpotato cultivars. Philippine Crop Sci. J. 5:30-33.

Clark, C.A. and J.W. Moyer. 1988. Compendium of sweetpotato diseases. APS Press, Minneapolis.

Clark, C.A., R.A. Valverde, S. Fuentes, L.F. Salazar, and J.W. Moyer. 2002. Research for improved management of sweetpotato pests and diseases, p. 103-112. In: T. Ames (ed.). Proceedings of the first international conference on sweetpotato food and health for the future. Acta Hort. 583.
Collins, W.W.,L.G. Wilson, S. Arrendell, and L.F. Dickey. 1987. Genotype $\times$ environment interactions in sweetpotato yield and quality factors. J. Amer. Soc. Hort. Sci. 112:579-583.

Dangler, J.M. 1994. Sweetpotato foundation programs provide sweetpotato growers with high quality pathogen-free stock. Compendium of sweetpotato foundation programs. HortTechnology 4:224.

Edmond, J.B. and G.R. Ammerman. 1971. Sweetpotatoes: Production, processing, and marketing. AVI, Westport, Conn.

Feng, G., G. Yifu, and Z. Pinbo. 2000. Production and deployment of virus-free sweetpotato in China. Crop Prot. 19: 105-111.

Gooding, H.J. 1964. Some aspects of the methods and results of sweetpotato selection. Emp. J. Expt. Agr. 32:279-289.

Groth, B.H.A. 1911. The sweetpotato. Bot. Lab. Univ. Pa. 4:(1).

Hahn, S.K. 1979. Effects of viruses (SPVD) on growth and yield of sweetpotato. Expt. Agr. 15:253-256.

Haigh, J. 1978. The accumulation of deleterious genes in a populationMuller's Ratchet. Theor. Pop. Biol. 14:251-267.

Harter, L.L. 1926. Mutations in the sweetpotato. J. Agr. Res. 33: $522-526$

Huett, D.O. 1982. Evaluation of sources of propagating-material for sweetpotato production. Scientia Hort. 16:1-7.

Jester, W.R., C.W. Averre, and J.R. Schultheis. 1994. Russet crack-like symptoms in Beauregard sweetpotato reduced by virus indexing and micropropagation. HortScience. 29: 727 (abstr.).

Kannua, M.B. and C.N. Floyd. 1988. Sweetpotato genotype $\times$ environment interactions in the highlands of Papua New Guinea. Trop. Agr. (Trinidad). 65:9-16.

Kano, Y. and R. Nagata. 1999. Comparison of rooting ability of virus infected and virus-free cuttings of sweetpotatoes (Ipomoea batatas Poir.) and an anatomical comparison of the roots. J. Hort. Sci. Biotechnol. 74(4):785-790.

Liao, C.H., M.L. Cumg, and T. Hsin-Sheng. 1983. Influence of sweetpotato viruses on the performances of some agronomic characteristics of sweetpotatoes. J. Agr. Res. China 32:228-232.

Milgram, M.J., J. Cohen, and G. Loebenstein. 1996. Effects of Sweet potato feathery mottle virus and Sweet potato sunken vein virus on sweetpotato yields and rates of reinfection of virus free planting material in Israel. Phytoparasitica 24:189-193.

Miller, J.C. 1930. A study of mutations of the Porto Rico sweetpotato. Proc. Amer. Soc. Hort. Sci. 343-346.

Miller, J.C. 1935. Further studies of mutations of the Porto Rico sweetpotato. Proc. Amer. Soc. Hort. Sci. 60.

Miller, J.C., T.P. Hernandez, T. Hernandez, and R.J. Barry. 1959. Sweetpotato foundation seed program for Louisiana. La. Agr. Expt. Sta. Cir. 58.

Moyer, J.W., J.A. Abad, J. New, and J. Bell. 2002. Isolation, identification and detection of undescribed RNA sweetpotato viruses, p. 121-127. In: T. Ames (ed.). Proceedings of the first international conference on sweetpotato food and health for the future. Acta Hort. 583.

Moyer, J.W. G.V.H. Jackson, and E.A. Friason. 1989. FAO/IBGR technical guidelines for the safe movement of sweetpotato germplasm. FAO/UN, IBGR, Rome.

Mukiibi, J. 1977. Effect of mosaic on the yield of sweetpotatoes in Uganda. Proc. 4th Intl. Soc. Trop. Roots, CIAT, Cali, Columbia. p. 169-170.

Muller, H.J. 1964. The relation of recombination to mutational advance. Mutation Res. 1:2-9.

Ngeve, J.M. 1990. Yield stability and yield depression in sweetpotato cultivars susceptible to the sweet potato virus disease. J. Hort. Sci. 65(2):225-230.

Ngeve, J.M. and J.C. Bouwkamp. 1991. Effects of Sweet potato virus disease (SPVD) on yield of sweetpotato. Expt. Agr. 27:221-225.

Ngeve, J.M. and J.C. Bouwkamp. 1993. Comparison of statistical methods to assess yield stability in sweetpotato. J. Amer. Soc. Hort. Sci. 118:304-310.

North Carolina Dept. of Agriculture and Consumer Services and Louisiana Dept. of Agriculture and Forestry. 2001. Marketing North Carolina sweetpotatoes including Louisiana: 2000-2001 crop. NCDA-CS. 
Raleigh, N.C.

Olivero, C.A. and T. Oropeza. 1985. Effects of the feathery mottle virus on yield and other agronomic parameters of cultivated sweetpotato. Agron. Trop. 35(1-3):167-172.

Pozzer,L., J.B.C. Silva,A.N. Dusi, and E.W. Kitajima. 1995. Performance of micropropagated sweetpotato plants after two field propagations and rate of reinfection by Sweet potato feathery mottle virus. Fitopatol. Bras. 20:464-468.

Rosa, J.T. 1926. Mutations in the sweetpotato. J. Hered. 17:167-168.

Rolston, L.H., C.A. Clark, J.M. Cannon, W.M. Randle, E.G. Riley, P.W. Wilson, and M.L. Robbins. 1987. 'Beauregard' sweetpotato. HortScience. 22:1338-1339.

Sanders, D.C. 2001. Vegetable crop guidelines for the southeastern U.S 2001-2002. United Agri-Products, Southeastern Univ. Ext. Serv., Vance Publ. p. 75.

SAS Institute. 1998. SAS/STAT users' guide, release 7.0. SAS Inst, Cary, N.C.

Schultheis, J.R. 1994. Virus-free micropropagated plants and clone effects on sweetpotato yield. HortScience 28:727 (abstr.).

Schultheis, J.R., W.W. Collins, and C.W. Averre. 1994. Micropropaga- tion, a means to enhance sweetpotato yield and quality. HortScience 29:466 (abstr.).

Souto, E.R., J. Sim, J. Chen, R.A. Valverde, and C.A. Clark. 2003. Properties of strains of Sweet potato feathery mottle virus and two newly recognized potyviruses infecting sweet potato in the United States. Plant Dis. (in press).

Templeton-Somers, K.M. and W.W. Collins. 1986. Field performance and clonal variability in sweetpotatoes propagated in vitro. J. Amer. Soc. Hort. Sci. 111:689-694.

Thompsom, H.C. 1929. Sweetpotato production. Orange Judd Publ. Co., New York.

U.S. Dept. of Agriculture. 1981. United States standards for grades of sweetpotatoes. U.S. Dept. Agr. Mktg. Serv., Wash., D.C.

Villordon, A.Q and D.R. LaBonte. 1995. Variation in randomly amplified DNA markers and storage root yield in 'Jewel' sweetpotato clones. J. Amer. Soc. Hort. Sci. 120:734-740.

Villordon, A.Q. and D.R. LaBonte. 1996. Genetic variation among sweetpotatoes propagated through nodal and adventitious sprouts. J. Amer. Soc. Hort. Sci. 121:170-174.

Wilson, L.G. and C.A. Averre. 1989. Growing and marketing quality sweet potatoes. N.C. Agr. Ext. Serv., N.C. State Univ., Raleigh. 